\title{
Health Care Sector as a Mammoth Challenge - A Comparative study of two fastest moving Economies of Asia
}

\author{
Kshirod Kumar Pradhan ${ }^{1}$ and R. S. V. Krishna ${ }^{2}$ \\ ${ }^{1}$ Principal and ${ }^{2}$ Associate Professor, \\ Vikash School of Business Management, Odisha, India.
}

CITATION: Pradhan, Kshirod Kumar and Krishna, R. S. V. (2019), "Health Care Sector as a Mammoth Challenge - A Comparative study of two fastest moving Economies of Asia", MERC Global's International Journal of Management, Vol. 7, Issue 4, pp. 286-289.

ARTICLE HISTORY: Submitted: May 17, 2019, Revision received: June 30, 2019, Accepted: July 10,2019

ARTICLE TYPE: Review article

\begin{abstract}
The present study focuses on the prevailing health care system in India and China taking into account some leading health indicators of both the Asian Giants, who are facing turbulent in dealing with the health care issues and challenges. The study has referred a large number of websites and publications dealing with Management of health data relevant to the health status of both the nations and finally selected six leading indicators like - Demographic, Socioeconomic, Health Status, Health Finance, Health Infrastructure and Human Resource in Health Sector. This study has also referred special reports of WHO, World Bank, UNICEF and National Health Profile (Govt. of India) for evaluating the status of both the nations with respect to the health parameters. The study attempted to highlight the key issues like shortage of Medical Personnel, facilities along with bulkier challenges like medical services not reaching all segments of people, thus creating a social imbalance. The comparison has been made with global average standards of selected parameters and the results would certainly help in policy and decision making in the improvement of health care sector in the country.
\end{abstract}

KEYWORDS: Leading health indicator, GDP, Health expenditure.

\section{BIBLIOGRAPHY}

1. Annual Health Survey Report: A Report on Core \& Vital Health Indicators, Part 1 (2012-13) prepared by Office of the Registrar General \& Census Commissioner, India; Ministry of Home Affairs, Govt. of India in collaboration with Institute of Economic Growth, Delhi University, North Campus.

2. Census of India - India at a Glance: Rural Urban Distribution, Web. 02 May 2012. http://www.censusindia.gov.in/Census_Data_2001/India_at_glance/rural.aspx

3. De, Jhilam Rudra (2008), Strategies to Cope Up With Disparities in Health Services in India, June 4.

4. Ghuman, B. S. and Mehta, A. (2009), "Health care services in India: Problems and Prospects", International Conference on the Asian Social Protection in Comparative Perspective.

5. Joumard, Isabelle and Kumar, Ankit (nd), Improving Health Outcomes and Health Care in India, OECD Economics Department, Working Papers No. 1184

6. Monitoring Health for SGDs, World Health Statistics (2018), World Health Organisation Report.

7. National Health Profile (2018), Central Bureau of Health Intelligence, Directorate General of Health Services, Ministry of Health \& Family Welfare, Govt. of India, $13^{\text {th }}$ Issue.

8. Peter, W. and Scheutz, Andreas M. (2013a), China's Health Care System-Overview and Quality Improvement; Growth Analysis Health Measurement Project commissioned by the Swedish Ministry of Health and Social Affairs.

9. Peter, W. and Scheutz, Andreas M. (2013b), India's Health Care System-Overview and Quality Improvement; Growth Analysis Health Measurement Project commissioned by the Swedish Ministry of Health and Social Affairs. 